\title{
Preoperative serum C-reactive protein levels and postoperative survival in patients with esophageal squamous cell carcinoma: a propensity score matching analysis
}

\author{
Wei Huang ${ }^{\dagger}$, Leilei $\mathrm{Wu}^{\dagger}$, Xuan Liư ${ }^{\dagger}$, Hao Long, Tiehua Rong and Guowei Ma*
}

\begin{abstract}
Objectives: This study tested the relationship between preoperative serum C-reactive protein (CRP) levels and cancer-specific prognosis in patients with esophageal squamous cell carcinoma who have undergone curative resection.

Methods: We conducted a retrospective study on 961 patients with esophageal squamous cell cancer who underwent curative esophagectomy from 2006 to 2012 at the Sun Yat-sen University Cancer Center. Preoperative serum CRP levels were determined, and a cutoff value of $5.0 \mathrm{mg} / \mathrm{mL}$ was established. Propensity score matching (PSM) was performed to reduce the selection bias between patients with low CRP $(\leq 5.0 \mathrm{mg} / \mathrm{mL})$ and those with high CRP (>5.0 mg/mL) levels based on age, tumor-lymph node-metastasis (TNM) stage, and tumor grade. The prognostic value of preoperative CRP levels was determined using life table, Kaplan-Meier, and Cox proportional hazards analyzes.

Results: In the unmatched cohort, the 3-year and 5-year survival rates were 57 and 53\%, respectively, in patients with high preoperative CRP levels ( $>5.0 \mathrm{mg} / \mathrm{mL}$ ) and 68 and $56 \%$, respectively, in those with low preoperative CRP levels $(\leq 5.0 \mathrm{mg} / \mathrm{mL})$. The difference in the survival rates of the 2 groups was significant $(p=0.004)$. Univariate survival analysis revealed that the preoperative CRP levels, TNM stage, tumor grade, drinking history, and anastomosis method were prognostic factors for overall survival (OS). Before conducting PSM, the low-CRP group had a lower age $(p=0.001)$, lower histological grade $(p=0.086)$, and lower TNM stage $(p=0.254)$.

After PSM, 176 patients with low CRP levels and 176 of those with high CRP levels were enrolled in the analysis. In the matched cohort, the 3-year and 5-year survival rates were 56 and 50\%, respectively, in patients with high preoperative CRP levels $(>5.0 \mathrm{mg} / \mathrm{mL}$ ) and 68 and $56 \%$, respectively, in those with low preoperative CRP levels $(\leq 5.0 \mathrm{mg} / \mathrm{mL}$ ). The difference in the survival rates between the low- and high-CRP groups was significant $(p=0.044)$. Multivariate analysis of the matched patients revealed that the TNM stage and preoperative CRP level were independent prognostic factors for OS.
\end{abstract}

Conclusions: A high preoperative CRP level $(>5.0 \mathrm{mg} / \mathrm{mL})$ predicts worse survival prognosis in patients who have undergone curative resection for esophageal squamous cell cancer.

Keywords: C-reactive protein, Curative resection, Esophageal cancer, Cutoff value, Survival analysis, Propensity scored matching

\footnotetext{
* Correspondence: magw@sysucc.org.cn

${ }^{\dagger}$ Huang Wei, Leilei Wu and Xuan Liu contributed equally to this work.

The Department of Thoracic Surgery, Sun Yat-sen University Cancer Center,

Guangdong Esophageal Cancer Institute, State Key Laboratory of Oncology

in South China, 651 Dongfengdong Road, Guangzhou Post Code: 510060,

China
}

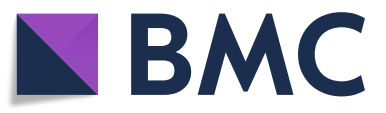

(c) The Author(s). 2019 Open Access This article is distributed under the terms of the Creative Commons Attribution 4.0 International License (http://creativecommons.org/licenses/by/4.0/), which permits unrestricted use, distribution, and reproduction in any medium, provided you give appropriate credit to the original author(s) and the source, provide a link to the Creative Commons license, and indicate if changes were made. The Creative Commons Public Domain Dedication waiver (http://creativecommons.org/publicdomain/zero/1.0/) applies to the data made available in this article, unless otherwise stated. 


\section{Introduction}

Esophageal cancer (EC) is a common cause of cancer-related deaths worldwide [1], and almost $50 \%$ of patients with EC live in China, where the most common histological type of this cancer is esophageal squamous cell carcinoma (ESCC) [2]. Complete surgical resection is the best treatment for patients with EC [3]. EC is generally diagnosed in the later stage and progresses rapidly; therefore, the overall survival (OS) rate of EC remains poor [4-6]. Thus, it is necessary to identify the predictive factors of prognosis in EC patients. Several markers have been reported for predicting the prognosis of this disease [7-10]; however, none has been widely used in clinical practice.

It is being increasingly acknowledged that the intrinsic properties of tumor cells and the host inflammatory response determine the spread of tumors. Creactive protein (CRP) is one of the acute-phase nonspecific proteins synthesized by the hepatocytes and regulated by interleukin-1, interleukin-6, and tumor necrosis factor (TNF) [11, 12]. Several reports have shown that a high preoperative serum CRP level is a disease-independent prognostic factor in a variety of tumors, such as those found in gastric cancer, lung cancer, renal cancer, and ovarian cancer [13-17]. Moreover, there are reports on a relationship between preoperative serum CRP levels and the prognosis of EC [18-22]. However, these studies were conducted on a small number of patients, and the imbalances between the groups in these retrospective analyzes may also have affected the results, resulting in indefinite conclusions. Owing to the inconsistent results, the role of serum CRP in EC remains controversial.

The present study aimed to test the relationship between preoperative serum CRP levels and EC-specific survival in patients who had undergone curative resection for esophageal squamous cell cancer. In order to arrive at a reliable conclusion, we ensured a good sample size $(n=961)$ in our study. The large sample size enabled us to perform propensity score analysis that allows matching of multiple factors to create similar groups for analysis. In this study, we performed a propensity-matched analysis of patients with high CRP levels and those with low CRP levels to identify the prognostic value of preoperative CRP levels.

\section{Materials and methods Patients}

We conducted a large-scale retrospective study by searching the EC database at the Department of Thoracic Surgery, Sun Yat-sen University Cancer Center, Guangzhou, China. Clinical and pathological data were extracted from the medical records. Baseline data included information on age, sex, consumption of alcohol and smoking, and preoperative serum CRP levels. We also examined the surgical conditions and tumor biological features, including surgical incisions, intraoperative procedures, type of surgery, postoperative stage, tumor invasion depth, lymph node metastasis ( $\mathrm{N}$ status), and tumor grade. The tumors were staged as per the American Joint Committee on Cancer (AJCC) Staging Manual (7th edition) [23]. For patients with EC, only tumor-lymph node-metastasis (TNM) stage I-III tumors were considered eligible for radical surgical resection and were included in this study. No patients had received neoadjuvant radio- or chemotherapy [24], while those who had received postoperative radioand/or chemotherapy were included. Patients with inflammatory diseases that influenced the preoperative serum CRP levels, such as infections and collagen disease, and those with primary cancers in other organs were excluded.

We enrolled 961 patients with esophageal squamous cell carcinoma who had undergone curative esophagectomy between 2006 and 2012 at the Department of Thoracic Surgery, Sun Yat-sen University Cancer Center. Patients were followed up until death or until study completion. Only patients who survived for at least 60 days postoperatively were enrolled. The median follow-up duration was 24 months, and the maximum follow-up duration was 67 months. Routine preoperative laboratory examinations were performed, including immunoturbidimetry, to determine the serum CRP levels. All the patients were terminally diagnosed at the pathological department at Sun Yat-sen University Cancer Center. The tumors were pathologically staged as per the AJCC Staging Manual (7th edition). However, because the data were collected over several years, some patients were staged according to the 6th edition before the 7th edition was published in 2009. We recorded the exact locations, invasion depths, positive lymph nodes, metastases, and tumor grades in detail after the surgery. These data were used to compute the location as well as the $\mathrm{T}, \mathrm{N}$, and $M$ stages of the tumor and subsequently stage the tumor according to the 7 th edition.

The institutional review board of the Sun Yat-sen University Cancer Center approved the present study, and the study was approved by the ethics committee of Sun Yat-sen University Cancer Center (Ethical approval number: YB2016-070).

\section{Analysis method}

A preoperative CRP level of $>5.0 \mathrm{mg} / \mathrm{mL}$ was considered high and was established as the cutoff $(5.0 \mathrm{mg} / \mathrm{mL})$ level using the professional X-tile program (version 
3.6.1, copyright Yale University 2003-05). Differences between the two groups of patients were compared using the chi-square test. Three- and 5-year survival rates were calculated using life table analysis. We compared the survival rates of patients with high and low preoperative CRP levels using Kaplan-Meier analysis and generated survival curves. The log-rank test was used to test the significance of the differences between the high- and low-CRP level groups. Multivariate survival analysis was performed to derive a final model of the variables exhibiting independent significant relationships, including all the covariates that were significant in the univariate analysis, with survival rate. All the analyzes were performed using SPSS (version 22.0, IBM SPSS, Inc.). A two-sided $p$ value of $<0.05$ was considered statistically significant.

Propensity score matching (PSM) was performed to reduce the bias due to age, TNM stage, and tumor grade. One-to-one matching without replacement was performed using a caliper-match algorithm, with the caliper width set to 0.05 times the standard deviation of the logit of the propensity score. The quality of matching was assessed by comparing the standardized differences between the treatment groups, with a threshold of 0.1 indicating good balance between the groups. This procedure was performed using STATA 12.0 (version 12.0, Stata Corp, College Station).

\section{Results}

Total 961 patients (749 men and 212 women; mean age, 58 years; range, $28-88$ years) were enrolled. The preoperative serum CRP levels were $>5.0 \mathrm{mg} / \mathrm{mL}$ (mean, $18.92 \mathrm{mg} / \mathrm{mL}$; median, $9.13 \mathrm{mg} / \mathrm{mL}$; standard deviation, $31.25 \mathrm{mg} / \mathrm{mL}$; range, $4.50-290.81 \mathrm{mg} / \mathrm{mL}$ ) in 250 patients and $\leq 5 \mathrm{mg} / \mathrm{mL}$ (mean, $1.54 \mathrm{mg} / \mathrm{mL}$; median, $1.25 \mathrm{mg} / \mathrm{mL}$; standard deviation, $1.09 \mathrm{mg} / \mathrm{mL}$; range, $0.06-4.48 \mathrm{mg} / \mathrm{mL}$ ) in 711 patients.

The clinicopathological characteristics of the patients are shown in Table 1. Before matching, there were significant differences in the distribution of age and the pathological $\mathrm{T}$ stage between patients with high preoperative CRP levels $(>5.0 \mathrm{mg} / \mathrm{mL})$ and those with low preoperative CRP levels $(\leq 5.0 \mathrm{mg} / \mathrm{mL})$. Three- and 5 year survival rates were 68 and 56\%, respectively, in patients with low preoperative CRP levels and 57 and 53\%, respectively, in those with high preoperative CRP levels. After PSM, 176 patients with a low CRP level and 176 patients with a high CRP level were enrolled. There were no significant differences in the distribution of the clinicopathological characteristics between patients with high preoperative CRP levels $(>5.0 \mathrm{mg} / \mathrm{mL})$ and those with low preoperative CRP levels $(\leq 5.0 \mathrm{mg} / \mathrm{mL})$. In the matched cohort, the differences in survival between the low- and high-CRP group remained significant $(p=0.044$, Fig. 1); the 3-year and 5-year survival rates were 56 and $50 \%$, respectively, in patients with high preoperative CRP levels $(>5.0 \mathrm{mg} / \mathrm{mL}$ ) and 68 and $56 \%$, respectively, in those with low preoperative CRP levels $(\leq 5.0 \mathrm{mg} / \mathrm{mL})$.

Before matching, univariate analysis showed that age $(p<0.001)$, TNM stage $(p=0.001)$, history of alcohol consumption $(p=0.024)$, tumor grade $(p=0.039)$, and preoperative serum CRP levels $(p=0.008)$ were significant risk factors for postoperative survival. Survival curves were used to illustrate the differences in the OS duration between patients with high and low preoperative CRP levels (Fig. 2). After matching, the univariate analysis showed that age $(p<0.001)$, TNM stage $(p<0.001)$, tumor site $(p<0.001)$, and preoperative serum CRP levels $(p=0.044)$ were significant risk factors for postoperative survival. Moreover, surgical incision was not a significant risk factor $(p=0.140)$. The factors mentioned above were included in the multivariate Cox regression analysis. The result showed that the TNM stage and the preoperative CRP level were independent prognostic factors for OS (Table 2).

\section{Discussion}

In China, the most common type of EC is squamous cell carcinoma. Therefore, our study focused on the prognosis of patients with this type of tumor. It has been reported that some factors may affect the prognosis of patients with $\mathrm{EC}$, such as patient status; tumor biological behavior, including the number of cancer-positive lymph nodes; histopathological cell type; histological grade; cancer location, including the esophagogastric junction; genetic mutations; and surgery type. However, no preoperative markers that can predict the prognosis of esophageal squamous cell carcinoma are currently widely used in clinical practice.

CRP is a representative reactant of acute and chronic phase inflammation. A link between inflammatory reactions and cancer has been reported by Virchow in 1863 that identified leukocyte infiltration in neoplastic tissues and suggested that these sites of chronic inflammation were the origin of the cancer [25]. There have also been reports of a relationship between inflammation and cancer progression [26]. It has now been widely accepted that the elevation in the preoperative serum CRP levels is a reliable indicator of poor postoperative prognosis in patients with certain malignancies, including those of the lung, kidney, ovary, and gastrointestinal tract. Recently, Ibuki et al. showed an association of postoperative CRP levels with poorer OS and recurrence-free survival [27, 28].

Some studies have reported a relationship between the prognosis of EC and preoperative CRP levels. However, these studies did not demonstrate a convincing relationship between these two parameters. 
Table 1 Clinicopathological features of the unmatched and propensity scored-matched patients

\begin{tabular}{|c|c|c|c|c|c|c|}
\hline \multirow{3}{*}{$\overline{\text { Gender }}$} & \multicolumn{3}{|l|}{ Unmatched } & \multicolumn{3}{|l|}{ Matched } \\
\hline & \multirow[t]{2}{*}{ Low CRP $(n=711)$} & \multirow[t]{2}{*}{ High CRP $(n=250)$} & \multirow[t]{2}{*}{$P$-value } & \multirow[t]{2}{*}{ Low $\operatorname{CRP}(n=176)$} & \multirow[t]{2}{*}{ High CRP $(n=176)$} & \multirow[t]{2}{*}{$P$-value } \\
\hline & & & & & & \\
\hline & $546(76.7 \%)$ & $203(81.2 \%)$ & 0.137 & $136(77.3 \%)$ & $141(80.1 \%)$ & 0.517 \\
\hline Female & $165(23.3 \%)$ & 47 (18.8\%) & & $40(22.7 \%)$ & 35 (19.9\%) & \\
\hline Age, y & $58(49,65)$ & $60(50,70)$ & 0.001 & $60(57-63)$ & $60(57-63)$ & 0.735 \\
\hline \multicolumn{7}{|l|}{ Smoking } \\
\hline Yes & 455 (64\%) & $173(69.2 \%)$ & 0.137 & $112(63.6 \%)$ & $121(68.7 \%)$ & 0.312 \\
\hline No & $256(36 \%)$ & 77 (30.8\%) & & 64 (36.4\%) & 55 (31.3\%) & \\
\hline \multicolumn{7}{|l|}{ Drinking } \\
\hline Yes & $238(33.5 \%)$ & $95(38.2 \%)$ & 0.182 & $62(35.2 \%)$ & 70 (39.4\%) & 0.417 \\
\hline No & $473(66.5 \%)$ & $155(61.8 \%)$ & & $114(64.8 \%)$ & $106(60.6 \%)$ & \\
\hline \multicolumn{7}{|l|}{ Tumor site } \\
\hline Cervix & $17(2.4 \%)$ & $1(0.4 \%)$ & & $6(3.4 \%)$ & $1(0.6 \%)$ & 0.777 \\
\hline Up & $104(14,6 \%)$ & 40 (16.0\%) & 0.635 & $22(12.5 \%)$ & $31(17.7 \%)$ & \\
\hline Middle & $350(49.3 \%)$ & $123(49.2 \%)$ & & 94 (53.4\%) & $83(47.4 \%)$ & \\
\hline Low & $240(33.7 \%)$ & $86(34.4 \%)$ & & $54(30.7 \%)$ & $60(34.2 \%)$ & \\
\hline \multicolumn{7}{|l|}{ TNM stage } \\
\hline IA & $6(0.8 \%)$ & $3(1.2 \%)$ & & $3(1.7 \%)$ & 0 & 0.970 \\
\hline $\mathrm{IB}$ & 94 (13.2\%) & $17(6.8 \%)$ & & $13(7.4 \%)$ & $18(10.2 \%)$ & \\
\hline$\| \mathrm{A}$ & $117(16.5 \%)$ & $44(17.6 \%)$ & 0.254 & $30(17.0 \%)$ & $32(18.2 \%)$ & \\
\hline$\| B$ & $194(27.3 \%)$ & $69(27.6 \%)$ & & $44(25.0)$ & 42 (23.9\%) & \\
\hline$\| \mathrm{A}$ & $158(22.2 \%)$ & 68 (27.2\%) & & 47 (26.7\%) & 44 (25.0\%) & \\
\hline$\| \mathrm{II}$ & $83(11.7 \%)$ & 35 (14\%) & & $26(14.8 \%)$ & $23(13.1 \%)$ & \\
\hline$\| I I C$ & $59(8.3 \%)$ & $14(5.6 \%)$ & & $13(7.4 \%)$ & 17 (9.7\%) & \\
\hline \multicolumn{7}{|c|}{ Differentiation } \\
\hline Well & 192 (27\%) & 86 (34.4\%) & & 57 (32.4\%) & 63 (35.3\%) & 0.823 \\
\hline Moderate & 404 (56.8\%) & $120(48.0 \%)$ & 0.086 & 85 (48.3\%) & 78 (44.3\%) & \\
\hline Poor & 115 (16.2\%) & 44 (17.6\%) & & 34 (19.3\%) & 36 (20.5\%) & \\
\hline \multicolumn{7}{|c|}{ Surgical incision } \\
\hline Left & $434(61.0 \%)$ & $165(66.0 \%)$ & 0.176 & $105(59.7 \%)$ & $117(66.5 \%)$ & 0.199 \\
\hline Right & 277 (39.0\%) & 85 (34.0\%) & & 71 (40.3\%) & 59 (33.5\%) & \\
\hline
\end{tabular}

Abbreviations: CRP C-reactive protein

The 2001 study by Nozoe et al. included 262 EC patients and showed that CRP can be an independent biomarker in patients with EC [22]. Thereafter, in 2003, Ikeda et al. gave the same conclusion based on their retrospective analyzes of the clinicopathological factors in 356 patients wherein they aimed to identify factors related to prognosis [29]. Gockel et al. investigated 291 EC patients who underwent curative resection and concluded that a high level of CRP ( $\geq 5 \mathrm{mg} / \mathrm{dL}$ ) is associated with tumor progression and poor OS [21]. The study by Wang et al. that included 123 patients showed that the pretreatment serum levels of CRP and albumin can be used to predict survival in EC patients treated with radiotherapy [30]. Furthermore, the preoperative CRP level can also play the same role in patients with small carcinoma of the esophagus or esophageal adenocarcinoma and in patients with early stage esophageal squamous cell carcinoma [19, 31, 32]. The report from Shimada et al. included patients with metastatic disease at the time of surgery and showed that the preoperative serum CRP levels could be a prognostic indicator in patients with esophageal squamous cell carcinoma [18]. A recent study from Otowa et al. showed that preoperative CRP level is a prognostic factor for cStage III EC [33]. All these studies showed that preoperative CRP level can be a significant prognostic indicator in EC patients. 


\section{Survival proportions: Matched Patients}

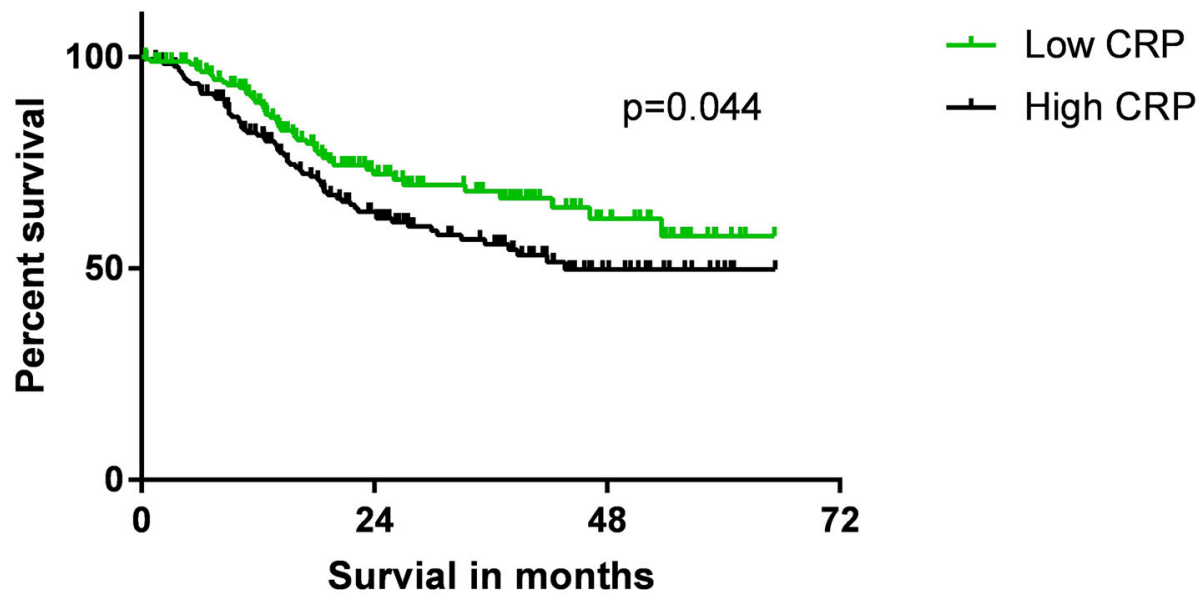

\begin{tabular}{|l|l|l|l|l|l|l|}
\hline Patients at risk & 0 Month & 12 Months & 24 Month & 36 Month & 48 Month & 60 Month \\
\hline High CRP & 176 & 125 & 75 & 51 & 18 & 3 \\
\hline Low CRP & 176 & 127 & 66 & 42 & 19 & 3 \\
\hline
\end{tabular}

Fig. 1 Kaplan-Meier-adjusted survival in postoperative esophageal squamous cell carcinoma patients. Overall survival of matched groups is shown

However, some contradictory reports also exist. The report by Zingg et al. showed significantly better survival in patients with normal CRP compared to that in patients with raised CRP levels among those who received neoadjuvant therapy that comprised 2 cycles of 5-fluorouracil (5-FU) and cisplatin in combination with 45-54 Gy of radiotherapy [34]. Owing to the inconsistent results, the role of serum CRP in EC remains controversial.

In addition, the sample size in previous studies was generally low. For example, Shimada et al. included 150 patients in the study, and only 35 patients were

\section{Survival proportions: Unmatched patients}

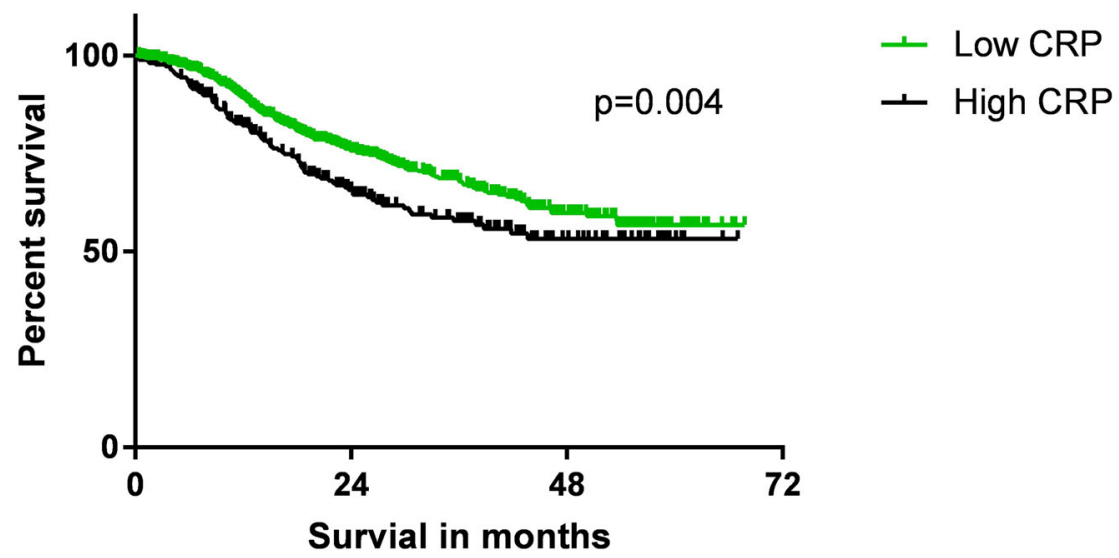

\begin{tabular}{|l|l|l|l|l|l|l|}
\hline Patients at risk & 0 Month & 12 Months & 24 Month & 36 Month & 48 Month & 60 Month \\
\hline High CRP & 711 & 632 & 540 & 483 & 426 & 398 \\
\hline Low CRP & 250 & 205 & 160 & 143 & 133 & 133 \\
\hline
\end{tabular}

Fig. 2 Kaplan-Meier-adjusted survival in postoperative esophageal squamous cell carcinoma patients. Overall survival of unmatched groups is shown 
Table 2 Univariable and Multivariable Cox Regression for overall survival After Propensity Score Matching

\begin{tabular}{llllll}
\hline Variables & $\begin{array}{l}\text { Univariable Analysis } \\
p \text {-value }\end{array}$ & \begin{tabular}{l} 
Multivariable Model \\
\cline { 3 - 6 }
\end{tabular} & $\begin{array}{l}p \text {-value } \\
\text { Age }\end{array}$ & 0.084 & \multicolumn{2}{c}{$\begin{array}{l}95 \% \mathrm{Cl} \text { for } \\
\operatorname{Exp}(\mathrm{B})\end{array}$} \\
\hline Smoking history & 0.717 & & & \\
Drinking history & 0.395 & & & & \\
CRP level & 0.044 & 0.022 & 0.646 & 0.443 & 0.942 \\
Tumor site & $<0.001$ & 0.087 & & & \\
Surgical incision & 0.140 & 0.295 & & & \\
Tumor grade & 0.734 & & & & \\
TNM stage & $<0.001$ & $<0.001$ & 1.485 & 1.299 & 1.699 \\
\hline
\end{tabular}

grouped into the high-CRP group. Similarly, Crumley et al. analyzed 120 patients; of these, only 15 exhibited high preoperative serum CRP levels. Therefore, the statistical power of these studies was weak because of the small number of patients. Owing to the limitation presented by the relatively smaller sample size, no study has performed PSM analysis to study the prognostic effect of CRP level. In our study, we included more patients (961) than those in previous studies. Moreover, PSM was performed to reduce the potential confounders. Before matching, the patients who exhibited high preoperative serum CRP levels had worse OS than those with low preoperative serum CRP levels $(p=0.004)$. In the matched cohort, the survival in the low-CRP group was better than that in the high-CRP group $(p=0.044)$. Additionally, multivariate Cox regression analysis of the matched patients showed that the CRP level was an independent prognostic factor for OS. As per the result, we concluded that the preoperative serum CRP level was an independent prognostic factor for patients with esophageal squamous cell carcinoma, a finding that is consistent with some previous reports.

Many factors, such as age and nutrition status, can affect the preoperative serum CRP levels [35]. By using PSM, the factors that affect CRP level can be balanced between the groups to some extent. In our study, the patients were well matched for age, tumor grade, and TNM stage. Univariate analysis showed that these three cofactors were significant risk factors for postoperative survival. After PSM, the difference between the two groups disappeared. Balanced grouping confirmed the conclusion. Another advantage of PSM is that after one-to-one matching, the high- and low-CRP groups had the same sample size.

Recently, some studies focus on the prognostic value of postoperative CRP level, and got some interesting results. In 2017, Ibuki et al. draw conclusion that the high postoperative CRP level can predict bad survival of patients who received esophagectomy [27]. Furthermore, this indicator can also predict the survival of patients with other carcinomas. In patients received non-small cell lung cancer resection, the research proposed by Shinohara showed that elevated 6-week postoperative C-reactive protein were related to worse OS [36]. The study by Pastorino et al. got a conclusion that the immediately elevated CRP level (postoperative day 3, 5, and 7) were related to worse outcome after surgery [37]. Furthermore, these studies indicate the predicative potential of postoperative serum CRP level, and the combination of preoperative and postoperative CRP may improve OS prediction in esophageal cancer patients. But in our study, we don't collect the data of the postoperative CRP level. Maybe we can pay more attention to this aspect in further research.

The present study has certain limitations. Although we attempted to offset the potential bias between the lowand high-CRP groups with PSM, the remaining bias may have affected the results.

\section{Conclusion}

In conclusion, after a careful comparison and a propensity score matching analysis, we found that the A high preoperative CRP level $(>5.0 \mathrm{mg} / \mathrm{mL})$ predicts worse survival prognosis in patients who have undergone curative resection for ESCC.

\section{Abbreviations \\ AJCC: American Joint Committee on Cancer; CRP: C-reactive protein; EC: Esophageal carcinoma; ESCC: Esophageal squamous cell carcinoma; OS: Overall survival, Lymph node status and metastasis; PSM: Propensity score matching; TNM: Tumor invasion depth,}

\section{Acknowledgments}

This work was supported by the Science and Technology Planning Project of Guangdong Province, China (No. 2013B022000040). The authors would like to thank Enago (www.enago.cn) for the English language review.

\section{Authors' contributions}

$\mathrm{WH}$ carried out the studies and drafted the manuscript. LW and $\mathrm{XL}$ participated in the design of the study and also performed the statistical analysis. HL, TR and GM conceived our research topic. GM also participated in the design coordination, and drafting of the manuscript. All authors read and approved the final manuscript.

\section{Funding}

This work was supported by the Science and Technology Planning Project of Guangdong Province, China (No. 2013B022000040). The funders did not have any role in study design; collection, analysis, and interpretation of data; writing the report; and the decision to submit the report for publication.

Availability of data and materials

Please contact author for data requests.

Ethics approval and consent to participate

The study was approved by the ethics committee of Sun Yat-sen University Cancer Center (Ethical approval number: YB2016-070). 


\section{Consent for publication}

Not applicable.

\section{Competing interests}

The authors declare that they have no competing interests.

Received: 30 March 2019 Accepted: 26 August 2019

Published online: 18 September 2019

\section{References}

1. Torre LA, Bray F, Siegel RL, Ferlay J, Lortet-Tieulent J, Jemal A. Global cancer statistics, 2012. CA Cancer J Clin. 2015;65:87-108.

2. Chen W, Zheng R, Zeng H, Zhang S, He J. Annual report on status of cancer in China, 2011. Chin J Cancer Res. 2015;27:2-12.

3. Enzinger PC, Mayer RJ. Esophageal cancer. N Engl J Med. 2003;349:2241-52.

4. Oezcelik A, Kaiser GM, Niebel W, Sleyman C, Treckmann JW, Sotiropoulos GC, et al. Ten-year survival of esophageal cancer after an en-bloc esophagectomy. J Surg Oncol. 2012;105:284-7.

5. Dresner SM, Griffin SM. Pattern of recurrence following radical oesophagectomy with two-field lymphadenectomy. Br J Surg. 2000;87: 1426-33.

6. Portale G, Peters JH, Hsieh CC, Tamhankar AP, Almogy G, Hagen JA, et al. Esophageal adenocarcinoma in patients $<$ or $=50$ years old: delayed diagnosis and advanced disease at presentation. Am Surg. 2004;70:954-8.

7. Shimada H, Takeda A, Nabeya Y, Okazumi Sl, Matsubara H, Funami Y, et al. Clinical significance of serum vascular endothelial growth factor in esophageal squamous cell carcinoma. Cancer. 2001;92:663-9.

8. Kaz AM, Grady WM. Epigenetic biomarkers in esophageal cancer. Cancer Lett. 2014:342:193-9.

9. Shimada H, Takeda A, Shiratori T, Nabeya Y, Okazumi S, Matsubara H, et al. Prognostic significance of serum thymidine phosphorylase concentration in esophageal squamous cell carcinoma. Cancer. 2002;94:1947-54.

10. Shimada H, Nabeya Y, Okazumi S, Matsubara H, Funami Y, Shiratori T, et al. Prognostic significance of serum p53 antibody in patients with esophageal squamous cell carcinoma. Surgery. 2002;132:41-7.

11. Castell JV, Gomez-Lechon MJ, David M, Fabra R, Trullenque R, Heinrich PC. Acute-phase response of human hepatocytes: regulation of acute-phase protein synthesis by interleukin-6. Hepatology. 1990;12:1179-86.

12. Gelin J, Moldawer LL, Lonnroth C, Sherry B, Chizzonite R, Lundholm K. Role of endogenous tumor necrosis factor alpha and interleukin 1 for experimental tumor growth and the development of cancer cachexia. Cancer Res. 1991;51:415-21.

13. Toriola AT, Grankvist K, Agborsangaya CB, Lukanova A, Lehtinen M, Surcel HM. Changes in pre-diagnostic serum C-reactive protein concentrations and ovarian cancer risk: a longitudinal study. Ann Oncol. 2011;22:1916-21.

14. Nozoe T, Iguchi T, Adachi E, Matsukuma A, Ezaki T. Preoperative elevation of serum C-reactive protein as an independent prognostic indicator for gastric cancer. Surg Today. 2011;41:510-3.

15. Michigan A, Johnson TV, Master VA. Preoperative C-reactive protein level adjusted for comorbidities and lifestyle factors predicts overall mortality in localized renal cell carcinoma. Mol Diagn Ther. 2011;15:229-34.

16. Chen HH, Chen IH, Liao CT, Wei FC, Lee LY, Huang SF. Preoperative circulating C-reactive protein levels predict pathological aggressiveness in oral squamous cell carcinoma: a retrospective clinical study. Clin Otolaryngol. 2011;36:147-53.

17. Park DS, Kim D, Hwang KE, Hwang YR, Park C, Seol CH, et al. Diagnostic value and prognostic significance of pleural C-reactive protein in lung cancer patients with malignant pleural effusions. Yonsei Med J. 2013;54: 396-402.

18. Shimada H, Nabeya Y, Okazumi S, Matsubara H, Shiratori T, Aoki T, et al. Elevation of preoperative serum C-reactive protein level is related to poor prognosis in esophageal squamous cell carcinoma. J Surg Oncol. 2003;83: 248-52.

19. Crumley AB, McMillan DC, McKernan M, Going JJ, Shearer CJ, Stuart RC. An elevated C-reactive protein concentration, prior to surgery, predicts poor cancer-specific survival in patients undergoing resection for gastrooesophageal cancer. Br J Cancer. 2006;94:1568-71.

20. Nozoe T, Matsumata T, Sugimachi K. Serum level of C-reactive protein may be a marker for proliferation of esophageal carcinoma. Hepatogastroenterology. 2000;47:1622-3.
21. Gockel I, Dirksen K, Messow CM, Junginger T. Significance of preoperative C-reactive protein as a parameter of the perioperative course and long-term prognosis in squamous cell carcinoma and adenocarcinoma of the oesophagus. World J Gastroenterol. 2006;12:3746-50.

22. Nozoe T, Saeki H, Sugimachi K. Significance of preoperative elevation of serum C-reactive protein as an indicator of prognosis in esophageal carcinoma. Am J Surg. 2001;182:197-201.

23. Edge SBBD, Compton CC, et al. AJCC cancer staging manual and 7th edition. New York: Springer; 2010.

24. Kaklamanos IG, Walker GR, Ferry K, Franceschi D, Livingstone AS. Neoadjuvant treatment for resectable cancer of the esophagus and the gastroesophageal junction: a meta-analysis of randomized clinical trials. Ann Surg Oncol. 2003;10:754-61.

25. Heys SD, Ogston KN, Simpson WG, Walker LG, Hutcheon AW, Sarkar TK, et al. Acute phase proteins in patients with large and locally advanced breast cancer treated with neo-adjuvant chemotherapy: response and survival. Int J Oncol. 1998;13:589-94.

26. Hussain SP, Harris CC. Inflammation and cancer: an ancient link with novel potentials. Int J Cancer. 2007;121:2373-80.

27. Ibuki Y, Hamai Y, Hihara J, Emi M, Taomoto J, Furukawa T, et al. Role of postoperative $\mathrm{C}$-reactive protein levels in predicting prognosis after surgical treatment of esophageal Cancer. World J Surg. 2017:41:1558-65.

28. Katsurahara K, Shiozaki A, Fujiwara H, Konishi H, Kudou M, Shoda K, et al. Relationship between postoperative CRP and prognosis in thoracic esophageal squamous cell carcinoma. Anticancer Res. 2018;38:6513-8.

29. Ikeda M, Natsugoe S, Ueno S, Baba M, Aikou T. Significant host- and tumorrelated factors for predicting prognosis in patients with esophageal carcinoma. Ann Surg. 2003;238:197-202.

30. Wang CY, Hsieh MJ, Chiu YC, Li SH, Huang HW, Fang FM, et al. Higher serum C-reactive protein concentration and hypoalbuminemia are poor prognostic indicators in patients with esophageal cancer undergoing radiotherapy. Radiother Oncol. 2009;92:270-5.

31. Feng JF, Zhao HG, Liu JS, Chen QX. Significance of preoperative C-reactive protein as a parameter in patients with small cell carcinoma of the esophagus. Onco Targets Ther. 2013;6:1147-51.

32. Song $Z B$, Lin BC, Li B, He CX, Zhang BB, Shao L, et al. Preoperative elevation of serum $C$-reactive protein as an indicator of poor prognosis for early-stage esophageal squamous cell carcinoma. Kaohsiung J Med Sci. 2013;29:662-6.

33. Otowa Y, Nakamura T, Yamazaki Y, Takiguchi G, Nakagawa A, Yamamoto M et al. Meaning of C-reactive protein around esophagectomy for cStage III esophageal cancer. Surg Today 2018.

34. Zingg U, Forberger J, Rajcic B, Langton C, Jamieson GG. Association of Creactive protein levels and long-term survival after neoadjuvant therapy and esophagectomy for esophageal cancer. J Gastrointest Surg. 2010;14:462-9.

35. Woloshin SSL. Distribution of C-reactive protein values in the United States. N Engl J Med. 2005;352:1611-3 2005.

36. Shinohara S, Otsuki RYO, Onitsuka T, Machida K, Matsuo M, Nakagawa M, et al. Postoperative C-reactive protein is a predictive biomarker for survival after non-small cell lung Cancer resection. Anticancer Res. 2019;39:2193-8.

37. Pastorino U, Morelli D, Leuzzi G, Gisabella M, Suatoni P, Taverna F, et al. Baseline and postoperative C-reactive protein levels predict mortality in operable lung cancer. Eur J Cancer. 2017;79:90-7.

\section{Publisher's Note}

Springer Nature remains neutral with regard to jurisdictional claims in published maps and institutional affiliations.

\section{Ready to submit your research? Choose BMC and benefit from:}

- fast, convenient online submission

- thorough peer review by experienced researchers in your field

- rapid publication on acceptance

- support for research data, including large and complex data types

- gold Open Access which fosters wider collaboration and increased citations

- maximum visibility for your research: over $100 \mathrm{M}$ website views per year

At BMC, research is always in progress.

Learn more biomedcentral.com/submissions 